\title{
Application of Motor Development Scale: an integrative review
}

\author{
Maria Cecilia Souza Santos ${ }^{1}$ \\ https://orcid.org/0000-0003-1668-5668 \\ Suraya Gomes Novais Shimano ${ }^{2}$ \\ https://orcid.org/0000-0002-9421-9227 \\ Larissa Giovanna de Oliveira Araújo' \\ https://orcid.org/0000-0001-8515-4671
}

Karina Pereira ${ }^{3}$

https://orcid.org/0000-0001-7486-1004
Universidade Federal do Triângulo Mineiro, Uberaba, Minas Gerais, Brasil.

Universidade Federal do Triângulo Mineiro, Departamento de Fisioterapia Aplicada, Uberaba, Minas Gerais, Brasil.

${ }^{3}$ Universidade Federal do Triângulo Mineiro, Departamento de Fisioterapia Aplicada e Programa de Pós-graduação em Fisioterapia, Uberaba, Minas Gerais, Brasil.

Study developed at the Federal University of Triângulo Mineiro, Uberaba, Minas Gerais, Brazil.

Conflict of interests: Nonexistent

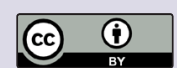

Received on: July 24, 2018 Approved on: April 5, 2019

Corresponding address:

Maria Cecilia Souza Santos

Rua: Doutor Afrânio, nº 115, apto. 706

Centro

CEP: 38440-072 - Araguari, Minas Gerais, Brasil

E-mail: ceciliacarizzi@gmail.com

\section{ABSTRACT}

Objective: to know, understand, and analyze studies that employed the Motor Development Scale as a method for motor evaluation.

Methods: the study included the databases Scielo, Pubmed, Lilacs, Science Direct, Web of Science, Scopus and Cochrane to identify the studies, using the following keywords: child; motor skills; motor skills disorders. The methodological quality of cross-sectional studies was analyzed by the Loney scale, cohort and case-control studies were assessed by the Newcastle-Ottawa scale, and clinical trials by the Physiotherapy Evidence Database.

Results: twenty studies met the inclusion criteria. There was predominance of cross-sectional studies, which had as main outcome the analysis of motor development of schoolchildren, children with obesity and overweight, premature, with Attention Deficit Hyperactivity Disorder, learning disabilities and Down syndrome. The studies presented objective criteria to measure the outcome and for interpretation and applicability of adequate results, although they did not reach the minimum score established by the assessment scales.

Conclusion: the Motor Development Scale is being used in Brazil in several contexts, presenting clear and statistically consistent results, although the methodologies of studies do not fully meet the standards of methodological quality.

Keywords: Child; Motor Skills; Motor Skills Disorders 


\section{INTRODUCTION}

The utilization of standardized scales and instruments to assess the motor development in childhood are common in the clinical practice and scientific research 1 . These instruments have allowed for professionals the early detection and understanding of the mechanisms and disorders of psychomotor development in children, besides aiding as a diagnostic screening tool for the planning of preventive or rehabilitative interventions based on scientific evidences in childhood ${ }^{2}$.

The Motor Development Scale (MDS) is a valid instrument in Brazil and is currently one of the most comprehensive scales for motor evaluation in children, including the main domains of psychomotricity: fine motricity, global motricity, balance, body scheme, spatial organization, temporal organization and laterality $^{3}$. The instrument may be applied to populations of children aged 2 to 11 years, allowing quantitative comparison of the motor age and chronological age.

In special education, the scale may be used to evaluate children with school learning difficulties, attention deficit-hyperactivity disorder (ADHD), anxiety, lack of motivation, neurological, mental and sensorial disorders, delayed neuropsychomotor development and disorders in speech, writing and calculation ${ }^{3,4}$.

Studies have also been found in different populations in the health area, including children with typical ${ }^{5-7}$ and atypical motor development, congenital heart disease $^{8}$, Williams syndrome ${ }^{9}$, autism ${ }^{10}$ and children with Down syndrome ${ }^{11}$. These authors observed delayed motor development in these children by comparing the chronological and motor ages.

Within this context, and considering the importance of using the scale to act in evidence-based practices, this study aimed to respond the following guiding question: in which contexts has the MDS been used?

Therefore, the study aimed to perform an integrative review, to know, understand and analyze the studies that employed the Motor Development Scale as a tool for motor evaluation.

\section{METHODS}

This review followed the steps for integrative review proposed by Mendes, Silveira and Galvão ${ }^{12}$.

The study used the databases Scielo, Pubmed, Lilacs, Science Direct, Web of Science, Scopus and Cochrane, by direct search using the keywords selected for the study and available in the Health Sciences Descriptors (DeCS) and the Medical Subject Headings (MeSH): "Children", "Motor Skills", "Motor Skills Disorders". Using these descriptors, the following combinations were used with the aid of Boolean indicators AND and OR for search in the databases: ("Child OR "Motor Skills") AND ("Child" OR Motor Skills Disorders").

The following inclusion criteria were considered: a) utilization of the Motor Development Scale; b) crosssectional, case-control, cohort, randomized clinical trial or nearly experimental study; c) Publications from 2008 to March 2018; d) journals scored as B1 or higher according to the Qualis classification in the field of Physical Education, and with minimum impact factor of 0.08; e) studies published in Portuguese, English and Spanish languages.

Two investigators independently performed the search on the databases. The combinations of keywords were inserted, and the studies were recorded on a spreadsheet. Duplicated studies and those that did not meet the inclusion criteria were excluded. Following, the selected references were read in full text. The information was organized according to the following criteria: authors, year of publication, country of origin, age, population, objective, study design and main outcomes.

The criteria of methodological quality of crosssectional studies were analyzed by the Loney scale ${ }^{13}$; longitudinal studies were assessed by the Newcastle Ottawa quality assessment scale cohort studies $(N O S)^{14}$, and the methodological quality of clinical trials was analyzed by the Physiotherapy Evidence Database scale (PEDro, 2011) ${ }^{15}$. The scoring of studies was performed by two independent examiners. In case of discordance, the studies were re-evaluated in combination until consensus was reached as to the final score.

Table 1 presents the analysis of methodological quality of cross-sectional studies by the Loney scale ${ }^{13}$. The items without scores in all studies refer to the lack of sample calculation (item 3) and blinding of examiners (item 5), which precluded the studies from reaching the methodological quality score advocated by the instrument (seven points). 
Table 1. Methodological quality of cross-sectional studies (Loney)

\begin{tabular}{|c|c|c|c|c|c|c|c|c|c|}
\hline \multirow{2}{*}{ References } & \multicolumn{6}{|c|}{ Are the study methods valid? } & \multirow{2}{*}{$\begin{array}{c}\text { What is the } \\
\text { interpretation of } \\
\text { results? }\end{array}$} & \multirow{2}{*}{$\begin{array}{c}\text { What is the } \\
\text { applicability of } \\
\text { results? } \\
8\end{array}$} & \multirow{2}{*}{ Total score } \\
\hline & 1 & 2 & 3 & 4 & 5 & 6 & & & \\
\hline Fonseca, Beltrame, Tkac ${ }^{16}$ (2008) & 1 & 1 & 0 & 1 & 0 & 1 & 1 & 1 & 6 \\
\hline Rocha, Rocha, Bertolasce ${ }^{17}$ (2010) & 1 & 1 & 0 & 1 & 0 & 1 & 1 & 1 & 6 \\
\hline Rosa Neto, Santos, Xavier, Amaro ${ }^{18}$ (2010) & 1 & 1 & 0 & 1 & 0 & 1 & 1 & 1 & 6 \\
\hline Rosa Neto, Santos, Weiss, Amaro ${ }^{19}$ (2010) & 1 & 1 & 0 & 1 & 0 & 1 & 1 & 1 & 6 \\
\hline Medina e Marques²0 (2010) & 1 & 1 & 0 & 1 & 0 & 1 & 1 & 1 & 6 \\
\hline Goulardins, Marques, Casella21 (2011) & 1 & 1 & 0 & 1 & 0 & 1 & 1 & 1 & 6 \\
\hline Okuda et al. ${ }^{22}$, (2011) & 1 & 1 & 0 & 1 & 0 & 1 & 1 & 1 & 6 \\
\hline Camargos et al. ${ }^{23},(2011)$ & 1 & 1 & 0 & 1 & 0 & 1 & 1 & 1 & 6 \\
\hline Goulardins et al. ${ }^{24}$, (2012) & 1 & 1 & 0 & 1 & 0 & 1 & 1 & 1 & 6 \\
\hline Rosa Neto et al. ${ }^{25},(2013)$ & 1 & 1 & 0 & 1 & 0 & 1 & 1 & 1 & 6 \\
\hline Santos, Neto, Pimenta ${ }^{26}$ (2013) & 1 & 1 & 0 & 1 & 0 & 1 & 1 & 1 & 6 \\
\hline Torquato et al. ${ }^{27}$, (2013) & 1 & 1 & 0 & 1 & 0 & 1 & 1 & 1 & 6 \\
\hline Bucco-Santos e González²8 (2013) & 1 & 1 & 0 & 1 & 0 & 1 & 1 & 1 & 6 \\
\hline Silva; Dounis ${ }^{29}$ (2014) & 1 & 1 & 0 & 1 & 0 & 1 & 1 & 1 & 6 \\
\hline Santos et al. ${ }^{30},(2015)$ & 1 & 1 & 0 & 1 & 0 & 1 & 1 & 1 & 6 \\
\hline Rosa Neto et al. ${ }^{31},(2015)$ & 1 & 1 & 0 & 1 & 0 & 1 & 1 & 1 & 6 \\
\hline Silva et al. ${ }^{32},(2016)$ & 1 & 1 & 0 & 1 & 0 & 1 & 1 & 1 & 6 \\
\hline
\end{tabular}

Legend: 1- Are the study design and sampling appropriate to respond the study question? 2- Is the sample adequate? 3- Is the sample size adequate? 4- Are adequate and standardized objective criteria used to assess the motor development? 5- Was the MDS applied in an unbiased manner?

6- Was the response rate adequate? 7- Were the results of MDS presented in detail? 8- Are the participants and context described in detail and can they be generalized for other situations?

Table 2 presents the methodological quality of nearly experimental studies, assessed by PEDro ${ }^{15}$. The studies had no scores in items related to the random distribution of groups (item 2), lack of subject blinding (item 5), therapists (item 6) and examiners (item 7). Therefore, the studies did not reach the methodological quality score advocated by the instrument (seven points).

Table 2. Methodological quality of nearly experimental studies (PEDro)

\begin{tabular}{ccccccccccccc}
\hline & \multicolumn{10}{c}{ Physiotherapy Evidence Database (PEDro ) } \\
\hline Studies & $\mathbf{1}$ & $\mathbf{2}$ & $\mathbf{3}$ & $\mathbf{4}$ & $\mathbf{5}$ & $\mathbf{6}$ & $\mathbf{7}$ & $\mathbf{8}$ & $\mathbf{9}$ & $\mathbf{1 0}$ & Total Score \\
\hline Fernani et al. ${ }^{33},(2013)$ & 1 & 0 & 0 & 1 & 0 & 0 & 0 & 1 & 1 & 1 & 5 \\
Silva et al. ${ }^{34},(2017)$ & 1 & 0 & 0 & 1 & 0 & 0 & 0 & 1 & 1 & 1 & 5 \\
\hline
\end{tabular}

Legend: 1- Specified eligibility criteria; 2- Subjects randomly distributed into groups; 3 - Blind allocation of subjects; 4- Groups were similar concerning the most important indicators of prognosis; $\mathbf{5}$ - Blinded individuals; $\mathbf{6}$ - Blinded therapists; $\mathbf{7}$ - Blinded examiners; $\mathbf{8}$ - Measurements of at least one key outcome were obtained in more than $85 \%$ of individuals initially distributed between groups; 9 - All subjects whose results were measured either received the treatment or the control condition according to the allocation or, when was not the case, data were analyzed for at least one of the key outcomes by "intention to treat"; 10- The results of statistical comparisons between groups were described for at least one key outcome. 
Table 3 presents the methodological quality of the longitudinal study by the NOS ${ }^{14}$, and the study did not score in items related to sample calculation (item 1 - selection), sample randomization (item 2 - selection), comparability of cohorts (items $1 \mathrm{a}$ and 1b - comparability) and lack of blinding of therapists and examiners (item 1 - results). Therefore, the study did not reach the methodological quality score advocated by the instrument (seven points).

Table 3. Methodological quality of longitudinal study (NOS)

\begin{tabular}{|c|c|c|c|c|c|c|c|c|c|c|}
\hline Studies & \multicolumn{10}{|c|}{ NOS - items scores } \\
\hline Criteria & $\begin{array}{c}\text { Selection } \\
1\end{array}$ & $\begin{array}{c}\text { Selection } \\
2\end{array}$ & $\begin{array}{c}\text { Selection } \\
3\end{array}$ & $\begin{array}{c}\text { Selection } \\
4\end{array}$ & $\begin{array}{c}\text { Comparability } \\
1 \mathrm{a}\end{array}$ & $\begin{array}{c}\text { Comparability } \\
1 \mathrm{~b}\end{array}$ & $\begin{array}{c}\text { Results } \\
1\end{array}$ & $\begin{array}{c}\text { Results } \\
2\end{array}$ & $\begin{array}{c}\text { Results } \\
3\end{array}$ & $\begin{array}{l}\text { Total } \\
\text { Score }\end{array}$ \\
\hline $\begin{array}{c}\text { Santos et al. }{ }^{35} \text {, } \\
\text { (2016) }\end{array}$ & 0 & 0 & 1 & 1 & 0 & 0 & 0 & 1 & 1 & 4 \\
\hline
\end{tabular}

Legend: selection 1: representativity of exposed cohort; selection 2: selection of unexposed cohort; selection 3: determination of exposure; selection 4: demonstration that the result of interest was not present at study onset; comparability $1 \mathbf{a}$ and $\mathbf{1 b}$ : comparability of cohorts based on the design or analysis; results $\mathbf{1}$ : evaluation of outcome; results 2: follow-up of cohorts; results 3: adequacy of follow-up of cohort

\section{LITERATURE REVIEW}

The electronic search retrieved 144 papers published in Portuguese, English and Spanish, among which 20 met the inclusion criteria (Figure 1).

The studies organized according to the aforementioned criteria are presented in Figure 2.

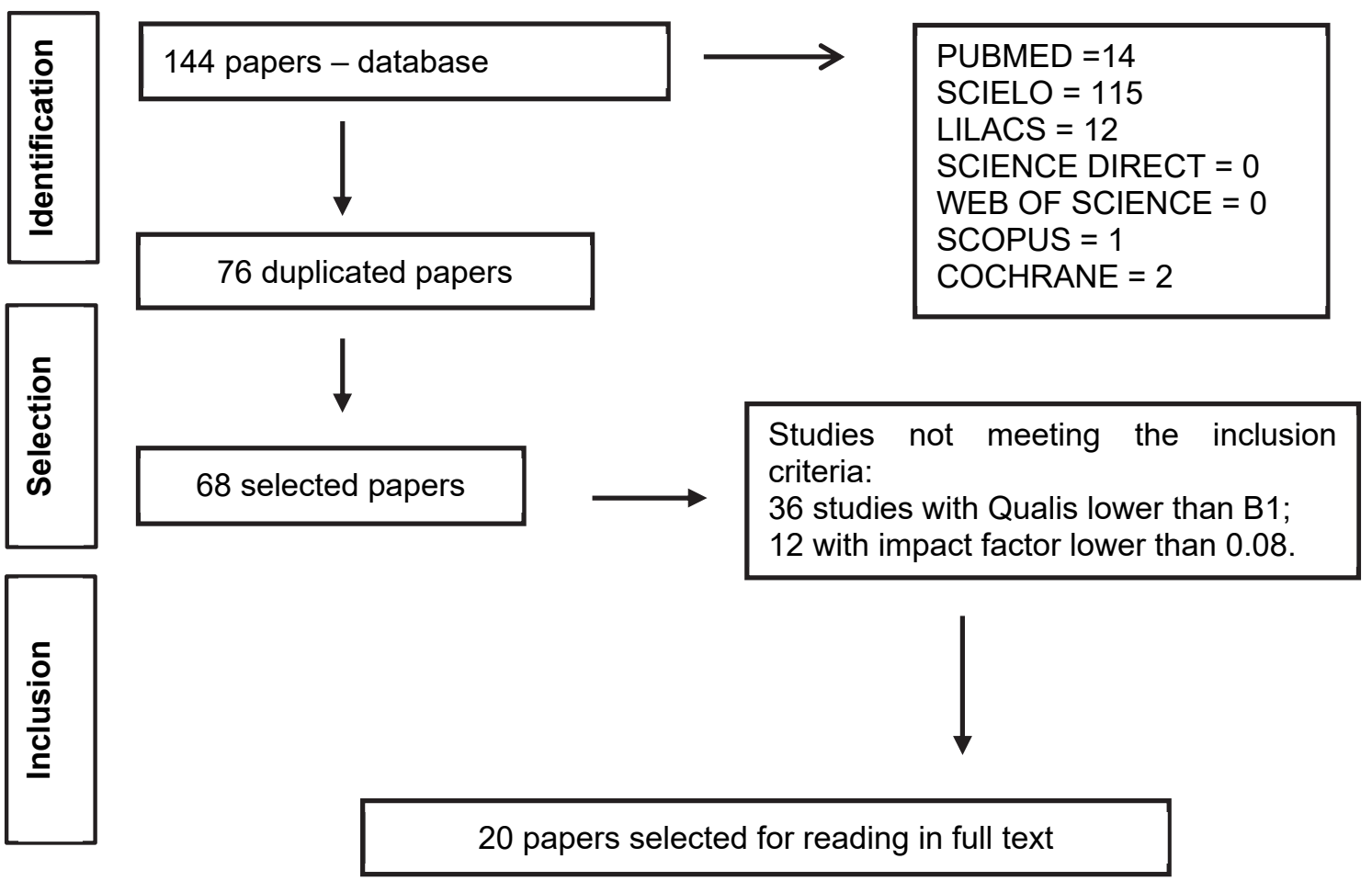

Figure 1. Flowchart of stages for references search 


\begin{tabular}{|c|c|c|c|c|c|c|c|}
\hline AUTHORS & YEAR & COUNTRY & AGE & SAMPLE & OBJECTIVE & $\begin{array}{l}\text { STUDY } \\
\text { DESIGN }\end{array}$ & OUTCOMES \\
\hline $\begin{array}{l}\text { Fonseca } \\
\text { et al. }{ }^{16}\end{array}$ & 2008 & Brazil & $\begin{array}{l}6 \text { to } 9 \\
\text { years }\end{array}$ & $\begin{array}{l}40 \text { children in } \\
\text { fundamental } \\
\text { school. }\end{array}$ & $\begin{array}{l}\text { To analyze the motor } \\
\text { development. }\end{array}$ & $\begin{array}{l}\text { Cross- } \\
\text { sectional }\end{array}$ & $\begin{array}{l}\text { Motor quotient scored as "normal } \\
\text { low" to "much higher" by the MDS. }\end{array}$ \\
\hline \multirow[b]{2}{*}{$\begin{array}{l}\text { Rocha } \\
\text { et al. } .^{17}\end{array}$} & \multirow[b]{2}{*}{2010} & \multirow[b]{2}{*}{ Brazil } & \multirow[b]{2}{*}{$\begin{array}{l}6 \text { to } 9 \\
\text { years }\end{array}$} & $\begin{array}{l}\text { Gl: } 40 \text { children } \\
\text { initiating futsal. }\end{array}$ & \multirow[b]{2}{*}{$\begin{array}{l}\text { To investigate the } \\
\text { contributions of sports } \\
\text { initiation for the motor } \\
\text { development. }\end{array}$} & \multirow[b]{2}{*}{$\begin{array}{l}\text { Cross- } \\
\text { sectional }\end{array}$} & \multirow[b]{2}{*}{$\begin{array}{l}\text { Children with more than six months } \\
\text { of practice presented higher } \\
\text { means of general motor age than } \\
\text { chronological age. }\end{array}$} \\
\hline & & & & $\begin{array}{l}\text { Gill: } 40 \text { children } \\
\text { practicing futsal } \\
\text { for at least six } \\
\text { months. }\end{array}$ & & & \\
\hline $\begin{array}{l}\text { Rosa Neto } \\
\text { et al. } .^{18}\end{array}$ & 2010 & Brazil & $\begin{array}{l}6 \text { to } 10 \\
\text { years }\end{array}$ & $\begin{array}{c}101 \text { schoolchildren } \\
\text { in fundamental } \\
\text { school. }\end{array}$ & Analysis of reliability of MDS. & $\begin{array}{l}\text { Cross- } \\
\text { sectional }\end{array}$ & $\begin{array}{c}\text { High correlation between } \\
\text { chronological and general motor } \\
\text { age indicated good internal } \\
\text { consistency }(0.889) \text { and reliability } \\
\text { of the MDS. }\end{array}$ \\
\hline $\begin{array}{l}\text { Rosa Neto } \\
\text { et al. } .^{19}\end{array}$ & 2010 & Brazil & $\begin{array}{l}6 \text { to } 10 \\
\text { years }\end{array}$ & $\begin{array}{c}101 \text { schoolchildren } \\
\text { in fundamental } \\
\text { school. }\end{array}$ & $\begin{array}{l}\text { Analysis of internal } \\
\text { consistency of fine motricity } \\
\text { tests of the MDS. }\end{array}$ & $\begin{array}{l}\text { Cross- } \\
\text { sectional }\end{array}$ & $\begin{array}{c}\begin{array}{c}\text { High correlation between thin and } \\
\text { general motor ages indicated good } \\
\text { internal consistency }(0.834) \text { of the } \\
\text { de tests. }\end{array} \\
\end{array}$ \\
\hline $\begin{array}{l}\text { Medina } \\
\text { et al. } .^{20}\end{array}$ & 2010 & Brazil & $\begin{array}{l}8 \text { to } 10 \\
\text { years }\end{array}$ & $\begin{array}{c}30 \text { children with } \\
\text { learning difficulty. }\end{array}$ & $\begin{array}{l}\text { To evaluate the motor } \\
\text { impairment. }\end{array}$ & $\begin{array}{l}\text { Cross- } \\
\text { sectional }\end{array}$ & $\begin{array}{l}\text { The motor age was lower than } \\
\text { the chronological age in all tests } \\
\text { analyzed. }\end{array}$ \\
\hline $\begin{array}{l}\text { Goulardins } \\
\text { et al. } .^{21}\end{array}$ & 2011 & Brazil & $\begin{array}{l}7 \text { to } 10 \\
\text { years }\end{array}$ & $\begin{array}{l}14 \text { children com } \\
\text { ADHD. }\end{array}$ & $\begin{array}{l}\text { To evaluate the psychomotor } \\
\text { profile of children with ADHD. }\end{array}$ & $\begin{array}{l}\text { Cross- } \\
\text { sectional }\end{array}$ & $\begin{array}{l}\text { The motor age was lower than } \\
\text { the chronological age in all tests } \\
\text { analyzed. }\end{array}$ \\
\hline \multirow{2}{*}{$\begin{array}{l}\text { Okuda } \\
\text { et al. } .^{22}\end{array}$} & \multirow{2}{*}{2011} & \multirow{2}{*}{ Brazil } & \multirow{2}{*}{$\begin{array}{l}6 \text { to } 11 \\
\text { years }\end{array}$} & $\begin{array}{l}\text { Gl: } 11 \\
\text { schoolchildren } \\
\text { with ADHD. }\end{array}$ & \multirow{2}{*}{$\begin{array}{l}\text { To compare the performance } \\
\text { of fine motor coordination } \\
\text { in schoolchildren using the } \\
\text { MDS. }\end{array}$} & \multirow{2}{*}{$\begin{array}{l}\text { Cross- } \\
\text { sectional }\end{array}$} & \multirow{2}{*}{$\begin{array}{c}\text { The thin motor age was lower than } \\
\text { the chronological age for both } \\
\text { groups. }\end{array}$} \\
\hline & & & & $\begin{array}{c}\text { Gll: } 11 \\
\text { schoolchildren } \\
\text { with dyslexia. }\end{array}$ & & & \\
\hline \multirow{2}{*}{$\begin{array}{l}\text { Camargos } \\
\text { et a. } .^{23}\end{array}$} & \multirow{2}{*}{2011} & \multirow{2}{*}{ Brazil } & \multirow{2}{*}{$\begin{array}{l}7 \text { and } 8 \\
\text { years }\end{array}$} & $\begin{array}{l}13 \text { premature } \\
\text { children. }\end{array}$ & \multirow{2}{*}{$\begin{array}{l}\text { To compare the motor } \\
\text { development of premature to } \\
\text { full-term children. }\end{array}$} & \multirow{2}{*}{$\begin{array}{l}\text { Cross- } \\
\text { sectional }\end{array}$} & \multirow{2}{*}{$\begin{array}{l}\text { Premature group: lower } \\
\text { performance in motor age and } \\
\text { motor quotient (fine motricity) } \\
\text { compared to full-term children. }\end{array}$} \\
\hline & & & & $\begin{array}{l}13 \text { children born } \\
\text { full term. }\end{array}$ & & & \\
\hline \multirow{2}{*}{$\begin{array}{l}\text { Goulardins } \\
\text { et al. } .^{24}\end{array}$} & \multirow[b]{2}{*}{2012} & \multirow[b]{2}{*}{ Brazil } & \multirow{2}{*}{$\begin{array}{l}7 \text { to } 11 \\
\text { years }\end{array}$} & $\begin{array}{l}\text { Gl: } 34 \text { children } \\
\text { with ADHD. }\end{array}$ & \multirow{2}{*}{$\begin{array}{l}\text { To evaluate the motor profile } \\
\text { of children with ADHD. }\end{array}$} & \multirow{2}{*}{$\begin{array}{l}\text { Cross- } \\
\text { sectional }\end{array}$} & $\begin{array}{l}\text { Children with ADHD achieved a } \\
\text { mean age of }-12.8 \text { months. }\end{array}$ \\
\hline & & & & $\begin{array}{l}\text { Gll: } 32 \text { typical } \\
\text { children. }\end{array}$ & & & $\begin{array}{l}\text { Children with typical motor } \\
\text { development, mean age }-3.9 \\
\text { months. }\end{array}$ \\
\hline $\begin{array}{l}\text { Rosa Neto } \\
\text { et al. } .^{25}\end{array}$ & 2013 & Brazil & $\begin{array}{l}8 \text { to } 9 \\
\text { years }\end{array}$ & $\begin{array}{c}166 \text { schoolchildren } \\
\text { in fundamental } \\
\text { school. }\end{array}$ & $\begin{array}{l}\text { To analyze the cross laterality } \\
\text { of schoolchildren with } \\
\text { application of MDS. }\end{array}$ & $\begin{array}{l}\text { Cross- } \\
\text { sectional }\end{array}$ & $\begin{array}{c}57.8 \% \text { of children presented } \\
\text { complete right laterality, } 33.1 \% \\
\text { "cross" laterality, } 7 \% \text { "undefined" } \\
\text { and } 2 \% \text { "left". }\end{array}$ \\
\hline \multirow{3}{*}{$\begin{array}{l}\text { Santos } \\
\text { et al..26 }\end{array}$} & \multirow{3}{*}{2013} & \multirow{3}{*}{ Brazil } & \multirow{3}{*}{$\begin{array}{l}8 \text { to } 9 \\
\text { years }\end{array}$} & $\begin{array}{l}\text { Gl: children not } \\
\text { participating in } \\
\text { projects. }\end{array}$ & \multirow{3}{*}{$\begin{array}{l}\text { To evaluate and compare } \\
\text { the motor abilities of } \\
\text { schoolchildren. }\end{array}$} & \multirow{3}{*}{$\begin{array}{l}\text { Cross- } \\
\text { sectional }\end{array}$} & \multirow{3}{*}{$\begin{array}{l}\text { The GIIl presented motor quotient } \\
\text { scored by the MDS as middle } \\
\text { normal in relation to Gll (low } \\
\text { normal) and Gl (low). }\end{array}$} \\
\hline & & & & $\begin{array}{c}\text { Gll: participants of } \\
\text { social projects. } \\
\end{array}$ & & & \\
\hline & & & & $\begin{array}{l}\text { GIll: participants of } \\
\text { sports projects. }\end{array}$ & & & \\
\hline \multirow{2}{*}{$\begin{array}{l}\text { Torquato } \\
\text { et al. } .^{27}\end{array}$} & 2013 & Brazil & 4 to 13 & 33 children with & $\begin{array}{l}\text { To analyze the motor } \\
\text { development of children } \\
\text { with Down syndrome who }\end{array}$ & Closs- & $\begin{array}{c}\text { Equine therapy group: normal low } \\
\text { motor quotient in balance and very } \\
\text { low in global motricity. } \\
\end{array}$ \\
\hline & $\angle 013$ & Braবlा & years & Down syndrome. & $\begin{array}{l}\text { practice equine therapy and } \\
\text { conventional physiotherapy. }\end{array}$ & sectional & $\begin{array}{l}\text { Physiotherapy group: middle } \\
\text { normal motor quotient in balance } \\
\text { and in global motricity. }\end{array}$ \\
\hline
\end{tabular}




\begin{tabular}{|c|c|c|c|c|c|c|c|}
\hline AUTHORS & YEAR & COUNTRY & AGE & SAMPLE & OBJECTIVE & $\begin{array}{l}\text { STUDY } \\
\text { DESIGN }\end{array}$ & OUTCOMES \\
\hline \multirow{3}{*}{$\begin{array}{l}\text { Bucco-dos } \\
\text { Santos } \\
\text { et al. }{ }^{28}\end{array}$} & \multirow{3}{*}{2013} & \multirow{3}{*}{ Spain } & \multirow{3}{*}{$\begin{array}{l}6 \text { to } 10 \\
\text { years }\end{array}$} & $\begin{array}{c}\text { Gl: } 100 \text { (normal } \\
\text { weight). }\end{array}$ & \multirow{3}{*}{$\begin{array}{c}\text { To analyze the motor profile } \\
\text { of children with overweight/ } \\
\text { obesity }\end{array}$} & \multirow{3}{*}{$\begin{array}{l}\text { Cross- } \\
\text { sectional }\end{array}$} & \multirow{3}{*}{$\begin{array}{l}\text { The GIll presented negative motor } \\
\text { age in all skills tested by the MDS } \\
\text { compared to the chronological age. }\end{array}$} \\
\hline & & & & $\begin{array}{c}\text { Gll: } 90 \\
\text { (overweight). }\end{array}$ & & & \\
\hline & & & & GIll: 94 (obesity). & & & \\
\hline $\begin{array}{l}\text { Silva } \\
\text { et al. }{ }^{29}\end{array}$ & 2014 & Brazil & $\begin{array}{l}9 \text { to } 11 \\
\text { years }\end{array}$ & $\begin{array}{l}43 \text { children in } \\
\text { fundamental } \\
\text { school. }\end{array}$ & $\begin{array}{l}\text { To delineate the motor } \\
\text { development profile of } \\
\text { children with low school } \\
\text { performance. }\end{array}$ & $\begin{array}{l}\text { Cross- } \\
\text { sectional }\end{array}$ & $\begin{array}{l}\text { The results demonstrated mean } \\
\text { of } 25.4 \text { months of motor delay in } \\
\text { relation to the chronological age } \\
\text { (negative age). }\end{array}$ \\
\hline \multirow[b]{2}{*}{$\begin{array}{l}\text { Santos } \\
\text { et al. }^{30}\end{array}$} & \multirow[b]{2}{*}{2015} & \multirow[b]{2}{*}{ Brazil } & \multirow[b]{2}{*}{$\begin{array}{l}7 \text { to } 10 \\
\text { years }\end{array}$} & $\begin{array}{l}\text { Control group: } 40 \\
\text { boys and } 40 \text { girls. }\end{array}$ & \multirow[b]{2}{*}{$\begin{array}{l}\text { To verify the impact of sports } \\
\text { practice in schoolchildren. }\end{array}$} & \multirow[b]{2}{*}{$\begin{array}{l}\text { Cross- } \\
\text { sectional }\end{array}$} & \multirow[b]{2}{*}{$\begin{array}{l}\text { The general motor quotient was } \\
\text { scored as higher in the systematic } \\
\text { practice group compared to the } \\
\text { schoolchildren group. }\end{array}$} \\
\hline & & & & $\begin{array}{l}\text { Systematic } \\
\text { practice group: } \\
40 \text { girls practicing } \\
\text { ballet and } 40 \text { boys } \\
\text { practicing futsal. }\end{array}$ & & & \\
\hline \multirow[t]{2}{*}{$\begin{array}{l}\text { Rosa Neto } \\
\text { et al. }{ }^{31}\end{array}$} & \multirow[t]{2}{*}{2015} & \multirow[t]{2}{*}{ Brazil } & \multirow[t]{2}{*}{$\begin{array}{l}5 \text { to } 10 \\
\text { years }\end{array}$} & $\begin{array}{l}\text { Gl: } 50 \text { children } \\
\text { with clinical } \\
\text { diagnosis of } \\
\text { ADHD. }\end{array}$ & \multirow[t]{2}{*}{$\begin{array}{l}\text { To compare the motor } \\
\text { development of children com } \\
\text { ADHD and typical children. }\end{array}$} & \multirow[t]{2}{*}{$\begin{array}{l}\text { Cross- } \\
\text { sectional }\end{array}$} & \multirow[t]{2}{*}{$\begin{array}{c}\text { Children with ADHD: negative motor } \\
\text { age of almost } 24 \text { months compared } \\
\text { to typical children. }\end{array}$} \\
\hline & & & & $\begin{array}{l}\text { Gll: } 150 \text { typical } \\
\text { children. }\end{array}$ & & & \\
\hline \multirow{2}{*}{$\begin{array}{l}\text { Silva } \\
\text { et al. }^{32}\end{array}$} & \multirow[b]{2}{*}{2016} & \multirow[b]{2}{*}{ Brazil } & \multirow[b]{2}{*}{3 years } & $\begin{array}{l}\text { Gl: } 10 \text { premature } \\
\text { children. }\end{array}$ & \multirow{2}{*}{$\begin{array}{l}\text { To compare the motor } \\
\text { development of premature } \\
\text { and full-term children. }\end{array}$} & \multirow{2}{*}{$\begin{array}{l}\text { Cross- } \\
\text { sectional }\end{array}$} & \multirow{2}{*}{$\begin{array}{l}\text { The group of full-term children } \\
\text { presented significant differences in } \\
\text { relation to the premature children in } \\
\text { thin and gross motor skills, spatial } \\
\text { and temporal organization. }\end{array}$} \\
\hline & & & & $\begin{array}{l}\text { Gll: } 10 \text { children } \\
\text { born full term. }\end{array}$ & & & \\
\hline $\begin{array}{l}\text { Fernani } \\
\text { et al. }^{33}\end{array}$ & 2013 & Brazil & $\begin{array}{l}6 \text { to } 11 \\
\text { years }\end{array}$ & $\begin{array}{l}28 \text { children with } \\
\text { delayed motor } \\
\text { development and } \\
\text { learning difficulty. }\end{array}$ & $\begin{array}{l}\text { To evaluate the motor } \\
\text { development before and } \\
\text { after application of motor } \\
\text { intervention. }\end{array}$ & $\begin{array}{c}\text { Nearly } \\
\text { experimental }\end{array}$ & $\begin{array}{l}\text { The general motor quotient was } \\
\text { chanted from normal low to middle } \\
\text { normal in most children. }\end{array}$ \\
\hline \multirow{2}{*}{$\begin{array}{l}\text { Silva } \\
\text { et al. }^{34}\end{array}$} & \multirow{2}{*}{2017} & \multirow{2}{*}{ Brazil } & \multirow{2}{*}{$\begin{array}{l}8 \text { to } 10 \\
\text { years }\end{array}$} & $\begin{array}{l}\text { CG: } 27 \text { children } \\
\text { (physical } \\
\text { education). }\end{array}$ & \multirow{2}{*}{$\begin{array}{c}\text { To evaluate the effects of } \\
\text { an intervention program in } \\
\text { schoolchildren aged eight to } \\
10 \text { years from public schools. }\end{array}$} & \multirow{2}{*}{$\begin{array}{c}\text { Nearly } \\
\text { experimental }\end{array}$} & \multirow{2}{*}{$\begin{array}{l}\text { GE: advances in fine motricity and } \\
\text { balance in relation to the control } \\
\text { group. }\end{array}$} \\
\hline & & & & $\begin{array}{l}\text { EG: } 27 \text { children } \\
\text { (psychomotor } \\
\text { intervention). }\end{array}$ & & & \\
\hline $\begin{array}{l}\text { Santos } \\
\text { et al. }^{35}\end{array}$ & 2016 & Brazil & $\begin{array}{l}6 \text { to } 24 \\
\text { months/ } \\
8 \text { to } 9 \\
\text { years }\end{array}$ & $\begin{array}{c}\text { Children with } \\
\text { delayed motor } \\
\text { development } \\
\text { assessed between } \\
6 \text { and } 24 \text { months. }\end{array}$ & $\begin{array}{l}\text { To analyze the } \\
\text { biopsychosocial profile of } \\
\text { children with delayed motor } \\
\text { development. }\end{array}$ & Longitudinal & $\begin{array}{l}\text { The general motor quotient } \\
\text { (GMQ) revealed delayed motor } \\
\text { development over time. In the } \\
\text { nursing period the children } \\
\text { were scored as "middle normal" } \\
\text { (GMQ=95.48) and over the years } \\
\text { as "low" (GMQ=75.23). }\end{array}$ \\
\hline
\end{tabular}

Legend: Gl: group I; GIl: group II; GIII: group III; MDS: motor development scale; ADHD: attention deficit-hyperactivity disorder; CG: control group; EG: experimental group.

Figure 2. Studies applying the Motor Development Scale

Concerning the categorization, regarding language, $65 \%$ of studies were published in Portuguese, $30 \%$ in English and 5\% in Spanish. Regarding the country of origin, all were conducted in Brazil. With regard to the journal, $90 \%$ of studies were published in national journals, and $10 \%$ in international. Among the selected studies, $85 \%$ were cross-sectional, presenting clear results concerning the objective.
Two studies in schoolchildren included validation of motor tests of the instrument and revealed high correlation between chronological age and general motor age, indicating good internal consistency of the MDS, ${ }^{18,19}$ and the children did not present delayed motor development.

In schoolchildren participating in sports social projects, the outcomes revealed advantages in 
the performance of all abilities tested by the MDS compared to children who did not participate ${ }^{26}$. Similar results were observed for the systematic practice of physical activity ${ }^{30}$. Children who participated in futsal for more than six months even presented higher motor age than the chronological age ${ }^{17}$.

The main outcomes in this population demonstrated the importance of access to physical activity for the motor development. The scientific evidences highlight these outcomes ${ }^{28,29,36}$, since the sports practice positively influences the child development. The investigators demonstrated that children with lower performance in locomotor skills are physically less active and motivated than children with greater motor skills ${ }^{28}$. The opportunity of access to physical activity, not necessarily monitored physical exercise, is a means to enhance the development and social aspects. Motor intervention programs also aided the acquisition of these abilities ${ }^{3,34}$.

The study proposed by Fernani et al. ${ }^{33}$ demonstrated that children with learning difficulties had improved results in body scheme, spatial and temporal organization tests. Schoolchildren submitted to a motor intervention program presented enhanced fine motricity and balance ${ }^{34}$.

The instrument has been used mainly for children with learning difficulties ${ }^{20,33,36,37}$ and ADHD $^{21,22,24,31,38}$, and the authors demonstrated an intrinsic correlation between motor development and learning ${ }^{25,29,33}$. Studies in children with attention deficit-hyperactivity disorder $(\mathrm{ADHD})^{21,22,24,31}$ evidenced that the motor age was lower than the chronological age in all studies, similar to investigations on children with learning difficulties ${ }^{29,33}$ and prematurely born ${ }^{23,32}$.

The study conducted on children with Down syndrome evidenced negative motor age ${ }^{27}$. However, the evidence-based practice demonstrated that the type of stimulation may influence the motor development of these children in different manners ${ }^{11}$. The study on children with overweight and obesity revealed significant delay in the motor development of participants, with negative impact on the obese ${ }^{28}$.

Schoolchildren with learning difficulties and low socioeconomic level presented delayed motor development during school age compared to the nursing period $^{35}$.

Most studies found in this review were conducted on children with typical motor development, and concerning sampling, the " $n$ " was larger in this population ${ }^{16-20}$. As observed, larger samples are expected in studies for situational diagnoses, such as those using this scale on schoolchildren. Conversely, smaller samples were observed for children with atypical motor development ${ }^{27}$, even due to the difficulty of previous clinical diagnosis.

Only one study on Down syndrome was conducted on children younger than 7 years ${ }^{27}$. At older age ranges, emphasis is given to studies on children with typical motor development, in whom the school environment was the main focus of studies, considering the ease to achieve a larger and more homogeneous sample.

The studies revealed that the MDS is a tool that allows the identification and analysis of motor development in childhood, addressing all relevant aspects of psychomotricity.

\section{CONCLUSION}

The integrative review allowed to identify that the MDS has been used in Brazil, in different contexts. Most studies were cross-sectional, with participants above 6 years of age, and were conducted in the population of schoolchildren with typical motor development and those with atypical one. The outcomes indicated detailed scientific evidences concerning the motor development of these populations, even though the studies did not meet the standards of methodological quality advocated by the assessment instruments employed.

\section{REFERENCES}

1. Madaschi V, Paula CS. Medidas de avaliação do desenvolvimento infantil: uma revisão da literatura nos últimos cinco anos. Cad Pós-Graduação Distur Desenvolv. 2011;11(1):52-6.

2. Vieira VEB, Ribeiro FV, Formiga CKMR. Principais instrumentos de avaliação do desenvolvimento da criança de zero a dois anos de idade. Rev Movimenta. 2009;2(1):23-31.

3. Rosa Neto F. Manual de Avaliação Motora.1a ed. Porto Alegre: ArtMed; 2002.

4. Rosa Neto F. Manual de Avaliação Motora: intervenção na educação infantil, ensino fundamental e educação especial. 3 a ed. revisada. Florianópolis: DIOESC; 2015.

5. Silva SLZR, Oliveira MCC, Ciasca SM. Desempenho percepto motor, psicomotor e intelectual de escolares com queixa de dificuldade de aprendizagem. Rev Psicopedgogia. 2017;103(34):33-44. 
6. Cardoso FGCC, Santos APM, Brusamarello S, Xavier RFC, Rosa Neto F. Validação das baterias de testes de motricidade global e equilíbrio da EDM. Rev Bras Ciênc Mov. 2009;17(2):1-17.

7. Amaro KN, Rosa Neto F, Brusamarello S, Corazza TDM. Validação de uma bateria de testes de organização espacial: Análise da consistência interna. Temas Desenvolv. 2010;17(100):179-82.

8. Leal LS, Silva RLM, Coelho KMS, Monteiro RPA, Montalvão TC. Avaliação do desenvolvimento motor de crianças portadoras de cardiopatia congênita. Int J Cardiovasc Sci. 2016;29(2):103-9.

9. Santos AMP, Portilla AMLL, Pereira F, Costa ANF, Rosa Neto $F$. Efeitos da intervenção motora em uma criança com síndrome de Williams. Rev Bras Ed Esp. 2015;21(3):423-32.

10. Rosa Neto F, Santos APM, Amaro KN, Gomes LJ. Efeitos da intervenção motora em uma criança com transtorno do espectro do autismo. Rev Bras Ed Esp. 2013;19(105):110-4.

11. Silva MNS, Santos KMB, Andrade LM, Zanoma AF. Avaliação funcional do desenvolvimento psicomotor e ambiente familiar de crianças com síndrome de Down. Rev Interinst Bras Ter Ocup. 2017;1(2):186-201.

12. Mendes KDS, Silveira RCCP, Galvão CM. Revisão integrativa: método de pesquisa para a incorporação de evidências na saúde e na enfermagem. Texto Contexto Enferm. 2008:17(4):758-64.

13. Loney PL, Chambers LW, Bennett KJ, Roberts JG, Stratford PW. Critical appraisal of the research literature: Prevalence or incidence of a health problem. Chronic Dis Can. 1998;19(4):170-6.

14. Stang A. Critical evaluation of the NewcastleOttawa scale for the assessment of the quality of nonrandomized studies in meta-analyses. Eur $\mathrm{J}$ Epidemiol. 2010;25(9):603-5.

15. Physiotherapy Evidence Database [Internet]. Sydney: PEDro; c1999-2006 [cited 2017 Nov 20]. Available from: http://www.pedro.org.au

16. Fonseca FR, Beltrame TS, Tkac CM. Relação entre o nível de desenvolvimento motor e variáveis do contexto de desenvolvimento de crianças. Rev Ed Fís/UEM. 2008;19(2):183-94.

17. Rocha PGM, Rocha DJO, Bertolasce AL. A influência da iniciação ao treinamento esportivo sobre o desenvolvimento motor na infância: um estudo de caso. Rev Ed Fis/UEM. 2010;21(3):469-77.
18. Rosa Neto F, Santos APM, Xavier RFC, Amaro KN. A importância da avaliação motora em escolares: análise da confiabilidade da Escala de Desenvolvimento Motor. Rev Bras Cineamtropom Desempenho Hum. 2010;12(6):422-7.

19. Rosa Neto F, Santos APM, Weiss SLI, Amaro KA. Análise da consistência interna de motricidade fina da EDM - Escala de Desenvolvimento Motor. Rev Educ Fis/UEM. 2010;21(2):191-7.

20. Medina-Papst J, Marques I. Avaliação do desenvolvimento motor de crianças com dificuldades de aprendizagem. Rev Bras Cineantropom Desempenho Hum. 2010;12(1):36-42.

21. Goulardins JB, Marques JCFB, Casella EB. Quality of life and psychomotor profile of children with attention deficit hyperactivity disorder (ADHD). Arq Neuropsiquiatr. 2011;69(4):630-5.

22. Okuda PMM, Lourencetti MD, Santos LCA, Padula NAMR, Capellini SA. Coordenação motora fina de escolares com dislexia e transtorno do déficit de atenção e hiperatividade. Rev. CEFAC. 2011;13(5):876-85.

23. Camargos ACR, Fontes PLB, Araújo APS, Silva FC, Pereira LP, Souza SMF. Desenvolvimento motor de crianças pré-termo moderadas aos sete e oito anos de idade. Rev Fisioter Pesqui. 2011;18(2):182-7.

24. Goulardins JB, Marques JCB, Casella EB, Nascimento RO, Oliveira JA. Motor profile of children with attention deficit hyperactivity disorder, combined type. Res Dev Disabil. 2012;34(1):40-5.

25. Rosa Neto F, Xavier RFC, Santos APM, Amaro KN, Florêncio R, Poeta LS. Cross-dominance and reading and writing outcomes in school-aged children. Rev. CEFAC. 2013;15(4):864-72.

26. Santos AM, Rosa Neto F, Pimenta RA. Avaliação das habilidades motoras de crianças participantes de projetos sociais/esportivos. Rev Motri. 2013;9(2):51-61.

27. Torquato JA, Lança AF, Pereira D, Carvalho FG, Silva RD. A aquisição da motricidade em crianças portadoras da Síndrome de Down que realizam fisioterapia ou praticam equoterapia. Fisioter Mov. 2013;26(3):515-24.

28. Buco-dos-Santos L, Gonzáles MZ. Desarrolo de las habilidades motoras fundamentales em función del sexo y del índice de massa corporal em escolares. Cuad Psicol Deporte. 2013;13(2):63-72.

29. Silva MNS, Dounis AB. Perfil do desenvolvimento motor de crianças entre 9 e 11 anos com baixo rendimento escolar da rede municipal de Maceió, AL. Cad Ter Ocup UFSCAR. 2014:22(1):63-70. 
30. Santos CR, Silva CC, Damasceno ML, MedinaPapst J, Marques I. Efeito da atividade esportiva sistematizada sobre o desenvolvimento motor de crianças dos sete aos dez anos de idade. Rev Educ Fis Esporte. 2015;29(3):497-506.

31. Rosa Neto F, Goulardins JB, Rigoli D, Piek JP, Oliveira JA. Motor development of children with attention déficit hyperactivity disorder. Rev Bras de Psiquiatr. 2015;37(3):228-34.

32. Silva JKM, Sargi AM, Andrade CCA, Araújo CC, Antônio TD. Motor development of preterm and term infants in the fundamental movement phase: a cross-sectional study. Fisioter Mov. 2016;29(3):518-88.

33. Fernani DCGL, Prado MTA, Fell RF, Reis NL, Bofi TC, Ribeiro EB et al. Motor intervention in children with school learning difficulties. Rev Bras Crescimento Desenvolv Hum. 2013;23(2):209-14.

34. Silva AZ, Pereira FLH, Mincewicz G, Araújo LB, Guimarães ATB, Israel VL. Psychomotor intervention to stimulate motor development in 8-10-year-old schoolchildren. Rev Bras Cineantropom Desempenho Hum. 2017;19(2):150-63.

35. Santos APM, Villaverde LN, Costa NF, Santos MO, Gregório EC, Andreis LM et al. Aspectos biopsicossociais em escolares com atraso no desenvolvimento motor: um estudo longitudinal. J Hum Growth Dev. 2016;26(1):112-8.

36. Rosa Neto F, Almeida GMF, Caon G, Ribeiro J, Caram JA, Piucco EC. Desenvolvimento motor de crianças com indicadores de dificuldades na aprendizagem escolar. Rev Bras Ciênc Mov. 2007;15(1):45-51.

37. Carvalho MC, Ciasca SM, Rodrigues SD. Há relação entre desenvolvimento psicomotor e dificuldade de aprendizagem? Estudo comparativo de crianças com Transtorno do Déficit de Atenção e Hiperatividade, dificuldade escolar e transtorno de aprendizagem. Rev Psicopedagogia. 2015;32(99):293-301.

38. Barbosa GO, Munster MAV. O efeito de um programa de equoterapia no desenvolvimento psicomotor de crianças com indicativos de transtorno do déficit de atenção e hiperatividade. Rev Bras Ed Esp. 2014;20(1)69-84. 